\title{
Giant Colonic Diverticula
}

\author{
Review of Diagnostic and Therapeutic Options
}

\author{
P. Steenvoorde ${ }^{\text {a }}$ F.J. Vogelaar ${ }^{a}$ J. Oskam ${ }^{a}$ R.A.E.M. Tollenaar ${ }^{b}$ \\ a Department of Surgery, Rijnland Hospital, Leiderdorp, and ' ${ }^{b}$ Department of Surgery, \\ Leiden University Medical Center, Leiden, The Netherlands
}

\section{Key Words}

Giant colonic diverticula $\cdot$ Diverticulosis $\cdot$ Barium enema Colectomy

\begin{abstract}
Background: A rare complication of diverticulosis of the colon is giant colonic diverticula (GCD). The condition was first described in English literature in 1953 [1, 2]. Methods: A Medline search was undertaken for English, French and German language articles on 'giant colonic diverticula'. Results: A total of 135 patients were identified, presenting with a total of 155 GCD [1-98]. With a complication rate of $28 \%$ and an operative mortality of $5 \%$, GCD seems to have a high clinical significance. Radiological examination of choice seems to be plain abdominal X-ray and CT examination, barium enema carries the risk of perforation of the diverticulum, and should not be performed. Conclusions: There are different therapeutic options, in our opinion diverticulectomy alone is not the treatment of choice. Because of the possibility of recurrence and oncological reasons, colectomy seems to be the best treatment. The creation of a protecting colostomy depends on other operative findings.
\end{abstract}

Copyright ( 2004 S. Karger AG, Base

\begin{tabular}{ll}
\hline KARGER & ( 2004 S. Karger AG, Basel \\
0253-4886/04/0211-0001\$21.00/0 \\
$\begin{array}{l}\text { Fax +4161306 12 34 } \\
\begin{array}{l}\text { E-Mail karger@karger.ch } \\
\text { www.karger.com }\end{array}\end{array}$ & $\begin{array}{l}\text { Accessible online at: } \\
\text { www.karger.com/dsu }\end{array}$
\end{tabular}

\section{Introduction}

Diverticulosis of the colon was a rare condition at the beginning of the 20th century with an incidence of $5 \%$, but now up to $50 \%$ of the people present with diverticulosis of the colon [99]. It is postulated that one of the reasons for this increase is a change of diet into a low-fiber diet [100]. Usually, colonic diverticula are asymptomatic, but bleeding or inflammatory conditions can necessitate surgical intervention. A rare complication of diverticulosis of the colon is giant colonic diverticula (GCD). The condition was first described in the French literature in 1946, and in the English literature in 1953.

A GCD is defined as a large colonic diverticulum, $4 \mathrm{~cm}$ in size or larger. Through a secondary ball-valve mechanism, gas enters the diverticulum, but is unable to leave the diverticulum, this leading to the formation of a GCD.

\section{Methods}

Published literature concerning GCD is mainly in the form of case reports, the largest reports describe only 5 cases [2, 27]. A Medline search was undertaken for English, French and German language articles on 'giant colonic diverticula'. Further papers were identified by cross-referencing from the reference lists of relevant articles. A total of 135 patients were identified, presenting with a total of 155 GCD $[1-98,101]$. Presenting symptoms and signs are reported. Relevant radiological work-up is discussed and therapeutic possibilities are reviewed.
P. Steenvoorde

Rijnland Hospital, Department of Surgery

Simon Smitweg 1

NL-2353 GA Leiderdorp (The Netherlands)

Tel. +31 71 5828282, E-Mail P.Steenvoorde@rijnland.nl 
Table 1. Symptoms of GCD

\begin{tabular}{lll}
\hline Symptoms & $\begin{array}{l}\text { Patients } \\
(\mathrm{n}=135)\end{array}$ & Percentage \\
\hline Abdominal pain & 93 & 68 \\
Constipation & 24 & 18 \\
Abdominal distention & 17 & 11 \\
Diarrhea & 17 & 11 \\
Vomiting & 16 & 12 \\
Nausea & 14 & 10 \\
Abdominal mass & 13 & 10 \\
Rectal bleeding/melena & 11 & 13 \\
Micturition problems* & 11 & 8 \\
Weight loss & 6 & 4 \\
Asymptomatic & 6 & 4 \\
Anorexia & 5 & 4 \\
Vaginal bleeding & 2 & 1 \\
\hline
\end{tabular}

* Hematuria, dysuria, pyuria, pneumaturia, retention, urinary frequency and enuresis.

One patient can have more complaints, therefore there are more than 135 complaints.

\section{Results}

Many different names describing GCD circulate. Giant sigmoid diverticulum is the most commonly used term (45\%), other names are: giant colonic diverticulum $(36 \%)$, giant gas cyst $(9 \%)$, giant air cyst $(5 \%)$, giant cyst $(2 \%)$ and other names (3\%). Because giant diverticula appear mostly $(81 \%)$, but not solely, in the sigmoid, the name giant colonic diverticulum is preferred [84].

From the 135 patients, 121 patients presented with a single diverticulum, 12 presented with a double GCD [6, $7,22,26,29,42,44,51,61,81,84,102]$, and 2 patients presented with multiple GCD [71, 93]. Most diverticula are found in the sigmoid 109/135 (81\%). The mean age of patients who present with a GCD is between 60 and 79 years.

Most GCD are 4-9 $\mathrm{cm}$ in diameter, with only a very small number which are larger than $25 \mathrm{~cm}$. There was no difference in size between the different histological types. The size of a GCD can vary over time. Nano et al. [78] discuss the phenomenon of a intermittently palpable mass, the reason they call it a phantom tumor, similar findings are reported by others as well $[5,50,52,71]$. Objective enlargement of the mass is found in 15 patients $[2,17,18,33,38,50,51,65,68,79,86,103]$. As Choong et al. [84] discuss, this increase in volume of a GCD can be related to differences in the intracolonic and GCD
Table 2. Physical signs of GCD

\begin{tabular}{lll}
\hline Physical signs & $\begin{array}{l}\text { Patients } \\
(\mathrm{n}=135)\end{array}$ & Percentage \\
\hline Abdominal mass, non-tender & 44 & 33 \\
Abdominal mass, tender & 34 & 25 \\
Fever & 28 & 21 \\
Abdominal tenderness & 15 & 11 \\
Normal & 12 & 9 \\
Acute abdomen & 10 & 7 \\
Abdominal distension & 8 & 6 \\
\hline
\end{tabular}

One patient can have more findings on physical examination, therefore there are more than 135 findings.

pressure through the communicating ostium. Higher intracolonic pressure would lead to higher pressure in the GCD, explaining the growth of GCD over time, this could also explain the phenomenon of the phantom tumor or the decrease in size of a GCD [23].

From the 135 studied cases, in 126 there is information about associated diverticulosis. In a total of $114 / 126$ $(90 \%)$ patients associated diverticulosis is present. There was no relationship between associated diverticulosis and different histological subgroups.

\section{Symptoms and Signs}

Abdominal pain (68\%), constipation (18\%) and vomiting $(12 \%)$ are the most reported symptoms of patients with GCD (table 1). On physical examination the typical patient presents with a non-tender abdominal mass (table 2). In total $28 \%(38 / 135)$ of GCD present with complications in which perforation and abscess formation are the two most reported complications. There is also a risk of the formation of carcinoma within the GCD, with a risk of $3 / 135(2 \%)$.

\section{Histological Confirmation}

Histologically, there are three different types of GCD [65]. The first type of a GCD is called a pseudo-diverticulum. A pseudo-diverticulum of the colon gradually increases in size, remnants of muscularis mucosa and muscularis propria may be found in the wall of the diverticulum. The mucosa is most of the times not completely intact. If no mucosal remnants at all are found, the GCD is considered a type II. Type II is called an inflammatory giant colonic diverticulum, which is actually a result from a local perforation of the mucosa with an abscess cavity 
that remains in contact with the lumen of the colon. Thewall of the diverticulum contains no portion of the bowel, but only reactive scar tissue. The third type of a GCD is the true diverticulum, in which the wall contains all layers of normal bowel wall, including serosa, muscularis, submucosa and mucosa [65].

There is no information about the histological diagnosis in 27 cases. This is largely due to two reasons, one is conservative treatment ( 10 cases) and the other reason is that it is simply not reported. The cases in which histological examination was performed revealed that 24 cases (22\%) could be classified as pseudodiverticula (type I GCD), $71(66 \%)$ as inflammatory giant colonic diverticulum (type II GCD) and 13 (12\%) as true diverticula (type III GCD).

Male to female ratio is equal in histological type I and type II. In histological type III (true diverticulum) there was a 6:1 male to female preponderance.

\section{Diagnostic Findings}

\section{Plain X-Ray}

Of 135 patients, 104 patients underwent a plain abdominal X-ray. Only one X-ray did not describe the classical picture of a gas-filled structure, in that case the diagnosis was made on lower abdominal contrast examination [28]. Pneumoperitoneum or pneumo-mesenterium, suggesting perforation of the gastrointestinal tract, was shown in 8 cases $[2,8,29,55,58,59,66,91]$. Besides the gas-filled cyst or free air, abdominal X-ray can show calcification [62]. On upright abdominal X-rays or lateral views a fluid level could be demonstrated in 15 (14\%) cases. This percentage would probably be higher, because in most cases, no upright X-ray is performed [4, 5, 9, 13, $15,18,28,32,36,39,40,50,69,75,80]$. A GCD can also be found on a plain X-thorax [68], but a normal X-thorax, does not exclude the presence of a GCD [36].

\section{Ultrasound Examination}

Ultrasound examination is described in 4 adult patients with a GCD $[78,87,91,98]$. Only in 1 case, where there was a diagnosis of perforation of a GCD, the ultrasound seemed helpful in the diagnosis [78]. In all other cases no abnormalities were seen. One case is described in which fetal ultrasound at 33 weeks of gestation was able to show an intra-abdominal cystic lesion, which turned out to be a GCD [97]. Ultrasound examination, in an adult patient, does not seem to be the radiologic examination of choice for detecting a GCD.

\section{Computed Tomography}

The CT demonstrates a thick-walled, air-filled cavity in close apposition to the adjacent colon [83]. CT examination revealed the GCD in all 17 patients in which $C T$ examination was performed $[61-63,65,67,74,80,82$, 84-91, 98]. Not only does it seem to be a sensitive investigation, it is also capable of identifying an existing communication between the cyst and the gastrointestinal tract, even when this could not be shown by barium enema investigation [63]. It can give additional information on the number of GCD [61], and on the presence of complications not seen on regular plain X-ray [88].

\section{Upper Barium Examination}

A barium meal (upper barium enema) was performed in 12 cases. In 2 cases a communication between the cystic lesion and the gastrointestinal tract could be detected $[33,36]$. In the other 10 cases $(83 \%)$ no communication was found [19, 26, 38, 41, 53, 63, 72, 80, 82, 89].

\section{Barium Enema}

A total of 111 barium enemas were performed, in a total of $71(64 \%)$ patients a communication could be visualized. Ritchie et al. [70] proved a communication of the GCD and the gastrointestinal tract, not by demonstration of barium inside the cyst, but on the expanding of the GCD on insufflation of air, if these 2 cases are also considered as positive, the total comes to $66 \%$. One of the complications of a barium enema examination in case of a GCD is perforation of the GCD, necessitating urgent surgical solution. Perforation of the GCD after barium enema within $24 \mathrm{~h}[38,58]$ and after $48 \mathrm{~h}$ [81] has been described.

\section{Colonoscopy}

Diagnostic colonoscopy is not considered to be helpful in the diagnosis of GCD [83]. It is thought that the ostium might be to small to allow visualization of the interior of the diverticulum. Mehta et al. [81] discuss the fact that in case of rectal bleeding, more and more colonoscopy is the first diagnostic procedure and that sometimes colonoscopic diagnosis of GCD is possible. Colonoscopy was performed in 18 patients. Colonoscopy did not demonstrate the GCD in 15 of $18(83 \%)$ described cases [2, 20, $26-28,30,40,42,43,48,54,58,72,74,78]$. In 3 cases colonoscopy revealed a large ostium of several centimeters suggesting a GCD $[52,71,81]$. It seems that for the work-up of a GCD, colonoscopy is not the diagnostic tool of choice, but that incidental diagnosis of GCD is possible with colonoscopy. 
Table 3. Different types of operations performed for GCD

\begin{tabular}{lll}
\hline Operation & $\begin{array}{l}\text { Patients } \\
(\mathrm{n}=135)\end{array}$ & Percentage \\
\hline Resection, primary anastomosis & 84 & 62 \\
Diverticulectomy & 17 & 13 \\
Resection, colostomy & 14 & 10 \\
Conservative* & 10 & 7 \\
Diverticulectomy, colostomy & 3 & 2 \\
Drainage & 3 & 2 \\
Not mentioned & 4 & 4 \\
\hline
\end{tabular}

* Including 3 patients who refused surgery. my depends on other operative findings, like associated perforation or abcess formation. Table 3 shows the different types of operations performed for GCD.

\section{Complications}

Non-fatal complications, like pneumonia or wound infection, occurred in 6 patients. From 135 studied patients, 10 patients were treated conservatively or refused surgery. The non-fatal complication rate is 5\% (6/125).

A total of 125 patients were operated, fatal complications of these interventions occurred in 5 patients $(5 \%)$. Fatal complications of diverticular disease are rare and occur in less than 1 in 10,000 cases of colonic diverticulosis [104]. In case of complicated diverticular disease, surgical mortality can even be $20 \%$ [105]. Fatal complications after surgical intervention for GCD is probably much higher because of selection of patients (most data in this review come from case reports). The total fatal and nonfatal complication rate is $9 \%(11 / 125)$.

\section{Conclusion}

A giant colonic diverticulum is a rare complication of colonic diverticular disease. In the literature, 135 patients are reported. With a complication rate of $28 \%$ and an operative mortality of $5 \%$, GCD seems to have a high clinical significance. In $2 \%$ of the cases, a carcinoma inside the GCD is found. Radiological examination of choice seems to be plain abdominal X-ray and CT examination. There is no role for ultrasound examination, colonoscopy or barium enema examination. There are different therapeutic options; in our opinion diverticulectomy alone is not the treatment of choice. Because of the possibility of recurrence of GCD and possible oncological reasons, colectomy seems to be the best option, the creation of a protecting colostomy depends on other operative findings.

\section{References}

1 Hughes WL, Greene RC: Solitary air cyst of the peritoneal cavity. Arch Surg 1953;67:931-936.

2 Kricun R, Stasik JJ, Reither RD, Dex WJ: Giant colonic diverticulum. AJR Am J Roentgenol 1980;135:507-512.

3 Boijsen E: Riesendivertikel im Sigmoid. Fortschr Geb Röntgenstr Nuklearmed 1956; 84:66-68

4 Case 43402: Case records of Massachusetts General Hospital. N Engl J Med 1957;257: 677-680.
5 Frankenfeld RH, Waters $\mathrm{CH}$, Schepeler TV: Giant air cyst of the abdomen: An unusual manifestation of diverticulitis of the sigmoid: Report of a case. Gastroenterology 1959;37: 103-106.

6 Melamed M, Pantone A: Giant diverticula of the colon. Arch Surg 1960;81:723-725.

7 Silberman EL, Thorner MC: Volvulus of giant sigmoid diverticulum. JAMA 1961;177:782784.
8 Macbeth WAAG, Riddle PR: Gas-filled abscess cavity as a manifestation of diverticulitis of the colon. Br J Radiol 1964;37:861-862.

9 Moore J, Gold C: Giant diverticulum of the sigmoid colon. Br J Surg 1964;51:876-878.

10 Bergeron RB, Hanley PH: Giant sigmoid diverticulum. Am J Surg 1965;109:660-662.

11 Ferguson WH, Boinis GA: A giant diverticulum of the colon: Report of a case. Med Ann Dist Columbia 1966;35:66-68. 
12 Fontaine R, Warter P, Bridier JJ, Philippe E: Giant abdominal gas cyst in a patient with sigmoidal diverticulosis. J Radiol Electrol Med Nucl 1966;47:657-662.

13 Beauchant J, Debelut J, Payard J, Fontaine A, Breuil J: Sigmoid cyst. Sem Hôp 1968;44: 1967-1968.

14 Finby N, Begg CF: Pneumocyst of colon. NY State J Med 1968;68:2941-2943.

15 Piper JV, Thornley BA: Solitary giant diverticulum of the sigmoid colon. Br J Surg 1968;55: 398-400.

16 Vanapruks S, Fuhrman M: Giant solitary gas cyst of the sigmoid colon: A case report. Radiology 1969;92:1533-1534.

17 Asch T, Milikow E, Gump F: Giant gas cyst of the sigmoid: Report of a case and review of the literature. Radiology 1970;96:409-410.

18 Barrat JG: Giant cyst of the sigmoid colon. Aust Radiol 1971;15:38-40.

19 Mainzer F, Minagi H: Giant sigmoid diverticulum. Am J Roentgenol Radium Ther Nucl Med 1971;113:352-354.

20 Swann JC, Giles KW: Giant diverticulum of the sigmoid colon. Br J Radiol 1971;44:551553.

21 Saha SP, Roesch CB: A giant sigmoid diverticulum: Report of a case. Dis Colon Rectum 1972; 15:63-65.

22 Schenken JR, Cochran R: An intestinal-gas cyst, a rare complication of diverticulitis: Report of a case. Dis Colon Rectum 1972;15:448452.

23 Sibson DE, Edwards AJ: Giant gas-filled cyst of sigmoid colon: Report of a case and review of the literature. Postgrad Med J 1972;48:180184.

24 Sagar S: Giant solitary diverticulum of the transverse colon with diverticulosis. $\mathrm{Br} \mathrm{J}$ Clin Pract 1973;27:145-146.

25 Joubaud F, Plane P, Bouali AB, Ronceray J, Barthe JP: Giant diverticulum of the colon. Sem Hôp 1974;50:2536-2537.

26 Kempczinski RF, Ferrucci JT Jr: Giant sigmoid diverticula: A review. Ann Surg 1974; 180:864-867.

27 Rabinowitz JG, Farman J, Dallemand S, Twerskey J, Rosen Y: Giant sigmoid diverticulum. Am J Roentgenol Radium Ther Nucl Med 1974; 121:338-343.

28 Smulewicz JJ, Govoni AF: Giant air cysts of the colon. J Can Assoc Radiol 1974;25:245250 .

29 Sutorius DJ, Bossert JE: Giant sigmoid diverticulum with perforation. Am J Surg 1974;127: 745-748.

30 Barlow B, Goodhue WW, Schullinger JN: Giant congenital diverticulum of the sigmoid colon. J Pediatr Surg 1975; 10:549-550.

31 Harris RD, Anderson JE, Wolf EA: Giant air cyst of the sigmoid complicating diverticulitis: Report of a case. Dis Colon Rectum 1975;18: 418-424.

32 Moss AA: Giant sigmoid diverticulum: Clinical and radiographic features. Am J Dig Dis 1975;20:676-683.

33 Johns ER, Hartley MG: Giant gas filled cysts of the sigmoid colon: A report of two cases. Br J Radiol 1976;49:930-931.
34 Beal JM: Case report: Giant diverticulum of sigmoid. Ill Med J 1977;151:272-273.

35 Camprodon R, Guerrero JA, Mendoza CG, Crespo C: Giant diverticula of the colon. Br J Surg 1977;64:628-629.

36 Foster DR, Ross B: Giant sigmoid diverticulum: Clinical and radiological features. Gut 1977; 18:1051-1053

37 Macleod DA, Jacques J: Solitary, paracolic gas cyst. Md State Med J 1977;26:74-77.

38 Ingram NP, Holford CP, Ellis WR: Two cases of giant intestinal gas cyst. Br J Surg 1978;65: 214.

39 Wetrich RM, Sidhu DS: Giant sigmoid diverticulum. West J Med 1978;128:539-541.

40 Wetstein L, Camera A, Trillo RA, Zamora BO: Giant sigmoidal diverticulum: Report of a case and review of the literature. Dis Colon Rectum 1978;21:110-112.

41 Arianoff AA, Vielle C, Arianoff V, Nouzaradan $\mathrm{J}$ : [Giant diverticulum of the sigmoid]. Acta Chir Belg 1979;78:223-229.

42 Gallagher JJ, Welch JP: Giant diverticular of the sigmoid colon: A review of differential diagnosis and operative management. Arch Surg 1979;114:1079-1083.

43 Teyssou H, Bureau M, Torras P, Ruiz R, Ter Davtian M, Tessier JP: [Giant diverticulum of the sigmoid: A report on one case and review of the literature (author's transl)]. J Radiol 1979; 60:439-443.

44 Cameron CR: Giant sigmoid diverticulum. J R Coll Surg Edinb 1980;25:457-459.

45 Ona FV, Salamone RP, Mehnert PJ: Giant sigmoid diverticulitis. A cause of partial small bowel obstruction. Am J Gastroenterol 1980; 73:350-352.

46 Slomic A, Saunders GM, Khor CY: [Giant diverticulum of the sigmoid]. J Can Assoc Radiol 1980;31:168-170.

47 Castagnone D, Ranzi T: Giant sigmoid diverticula. Case report and review. Panminerva Med 1981;23:203-206.

48 Cronin TG Jr, Tway MS, Boraca CT: Recurrent giant air cyst of the colon. IMJ Ill Med J 1981;160:40-42.

49 Heimann T, Aufses AH Jr: Giant sigmoid diverticula. Dis Colon Rectum 1981;24:468470 .

50 Maresca L, Maresca C, Erickson E: Giant sigmoid diverticulum: Report of a case. Dis Colon Rectum 1981;24:191-195.

51 Muhletaler CA, Berger JL, Robinette CL Jr: Pathogenesis of giant colonic diverticula. Gastrointest Radiol 1981;6:217-222.

52 Rosenberg RF, Naidich JB: Plain film recognition of giant colonic diverticulum. Am J Gastroenterol 1981;76:59-69.

53 Wallers KJ: Giant diverticulum arising from the transverse colon of a patient with diverticulosis. Br J Radiol 1981;54:683-688.

54 Pinsolle J, Riviere J, Boisseau C, Videau J: [Giant diverticulum of the sigmoid colon. A rare complication of colonic diverticulosis. Review of the literature apropos of a case]. J Chir (Paris) 1982;119:583-587.

55 Al Jurf AS, Foucar E: Uncommon features of giant colonic diverticula. Dis Colon Rectum 1983;26:808-813.
56 Moesgaard J, Felding C: Giant diverticulum of the sigmoid colon. Acta Chir Scand 1983;149: 445-447.

57 Patel D, Diab W: Giant colonic diverticulum. N.Y. State J Med 1983;83:750-754.

58 Ricci MA, Cady D: Giant colonic diverticulum. NY State J Med 1983;83:1153.

59 Cullen GM, Wepfer JF: Giant gas cysts of the sigmoid colon. Wis Med J 1984;83:17-18.

60 van Vugt AB, Sleeboom C, Dekker LA, Mallens WM, ten Velde J: Giant cysts in diverticular disease of the sigmoid colon. Neth J Surg 1985;37:183-186

61 Siskind BN, Burrell MI, Richter JO, Radin DR: CT appearance of giant sigmoid diverticulum. J Comput Assist Tomogr 1986;10:543544.

62 Fields SI, Haskell L, Libson E: CT appearance of giant colonic diverticulum. Gastrointest Radiol 1987;12:71-72.

63 Smith TR, Tyler IM: CT demonstration of a giant colonic diverticulum. Gastrointest $\mathrm{Ra}-$ diol 1987;12:73-75.

64 Lapeyrie H, Balmes P, Loizon P, Delhoume JY: [Giant diverticulum of the transverse colon]. J Chir (Paris) 1988;125:717-720.

65 McNutt R, Schmitt D, Schulte W: Giant colonic diverticula - three distinct entities. Report of a case. Dis Colon Rectum 1988;31:624628.

66 Marechal A, Brousse P, Rousseau J: [Giant diverticulum of the colon. Apropos of 2 cases] J Radiol 1989;70:43-46.

67 van Niekerk AJ, Fourie PA: Giant colonic diverticulum - a radiological diagnostic problem. A case report. S Afr Med J 1989;75:447448.

68 Scerpella PR, Bodensteiner JA: Giant sigmoid diverticula. Report of two cases. Arch Surg 1989;124:1244-1246.

69 Fontanelle L, Le Goff JY, Convard JP: [Giant diverticulum of the colon. Apropos of a case disclosed by complication]. Ann Radiol (Paris) 1991:34:398-400

70 Ritchie AJ, Carson JG, Humphreys WG: Encysted pneumatocele: A complication of diverticular disease. Br J Surg 1991;78:683.

71 Agarwal DK, Choudhuri G, Dhiman RK, Kapoor VK: Giant colonic diverticulae presenting as painless abdominal lump. Indian J Gastroenterol 1992;11:90.

72 Levi DM, Levi JU, Rogers AI, Bergau DK, Wenger J: Giant colonic diverticulum: An unusual manifestation of a common disease. Am J Gastroenterol 1993;88:139-142.

73 Slawson SH, Sykes MW, Binkovitz LA: Giant pseudodiverticulum of the sigmoid colon. Mayo Clin Proc 1993;68:707-708.

74 Nagler-Reus M, Guhl L, Arlart IP: [Giant diverticulum of the sigmoid colon]. Rofo Fortschr Geb Röntgenstr neuen Bildgeb Verfahr 1994;161:171-173.

75 Scully RE, Mark EJ, McNeely WF, McNeely BU: Case records of the Massachusetts General Hospital, case 19-1994. N Engl J Med 1994 330:1376-1381.

76 Naber A, Sliutz AM, Freitas H: Giant diverticulum of the sigmoid colon. Br J Surg 1995;82: 985. 
77 Naber A, Sliutz AM, Freitas H: Giant diverticulum of the sigmoid colon. Int J Colorectal Dis 1995; 10:169-172.

78 Nano M, De Simone M, Lanfranco G, et al: Giant sigmoid diverticulum. Panminerva Med 1995;37:44-48.

79 Ueda P, Hall D: Images in clinical medicine. Giant colonic diverticulum. N Engl J Med 1995;333:228.

80 D’Almeida MJ, McQuiston JH: Giant sigmoid diverticulum. J Am Osteopath Assoc 1996;96: 309-313.

81 Mehta DC, Baum JA, Dave PB, Gumaste VV Giant sigmoid diverticulum: Report of two cases and endoscopic recognition. Am J Gastroenterol 1996;91:1269-1271.

82 Roger T, Rommens J, Bailly J, Vollont GH, Belva P, Delcour C: Giant colonic diverticulum: Presentation of one case and review of the literature. Abdom Imaging 1996;21:530-533.

83 de Oliveira NC, Welch JP: Giant diverticula of the colon: a clinical assessment. Am J Gastroenterol 1997;92:1092-1096.

84 Choong CK, Frizelle FA: Giant colonic diverticulum: Report of four cases and review of the literature. Dis Colon Rectum 1998;41:11781185

85 Grover H, Nair S, Hertan H: Giant true diverticulum of sigmoid colon. Am J Gastroenterol 1998;93:2267-2268.

86 Kuganeswaran E, Fisher JK: Giant sigmoid diverticulum: a rare manifestation of diverticular disease. South Med J 1998;91:952-955.
87 Custer TJ, Blevins DV, Vara TM: Giant colonic diverticulum: A rare manifestation of a common disease. J Gastrointest Surg 1999;3: 543-548.

88 Diaz Candamio MJ, Pombo F, Yebra MT: Amyloidosis presenting as a perforated giant colonic diverticulum. Eur Radiol 1999;9:715718.

89 Havenstrite KA, Harris JA, Rivera DE: Giant colonic diverticulum: Report of a case. Am Surg 1999;65:578-580.

90 Naing T, Ray S, Loughran CF: Giant sigmoid diverticulum: A report of three cases. Clin Radiol 1999;54:179-181.

91 Roth T, Demartines N, Gavelli A, Huguet C: [Giant diverticula of the colon. Apropos of 2 cases]. Chirurgie 1999;124:307-312.

92 Arima N, Tanimoto A, Hamada T, Sasaguri Y, Sasaki E, Shimokobe T: MALT lymphoma arising in giant diverticulum of ascending colon. Am J Gastroenterol 2000;95:3673-3674.

93 Brouland JP, Poupard B, Nemeth J, Valleur P: Lipomatous polyposis of the colon with multiple lipomas of peritoneal folds and giant diverticulosis: Report of a case. Dis Colon Rectum 2000;43:1767-1769.

94 Gendy RK, Jeffery PJ: Giant diverticulum of colon treated by diverticulectomy. Hosp Med 2000;61:362.

95 Majeski J, Durst G Jr: Obstructing giant colonic diverticulum. South Med J 2000;93:797799.

96 Philip J, Whittlestone TH, Hamilton SG: An unusual case of acute urinary retention. BJU Int 2000;85:557-554
97 Rosen NG, Gibbs DL, Soffer SZ, Valderrama E, Lee TK: Uroepithelium in a colonic diverticulum. J Pediatr Surg 2000;35:1375-1376.

98 Steenvoorde P, Tollenaar RAEM: Gastrointestinal: Giant inflammatory colonic diverticulum. J Gastroenterol Hepatol 2002; 17:805.

99 Cotran RS, Kumar V, Robbins SL: Robbins Pathologic Basis of Disease. Philadelphia, Saunders, 1989, pp 884-885.

100 Elfrink RJ, Miedema BW: Colonic diverticula. When complications require surgery and when they don't. Postgrad Med 1992;92:972, 105, 108 .

101 Bonvin P, Bonte G: Diverticules géants du sigmoide. Arch Mal Dig Mal Nutr 1946;35: 353-355.

102 Casas DJ, Tenesa M, Alastrue A, Hidalgo F Barranco LC, Olazabal A: Case report: Uncommon radiological and pathological features of giant colonic diverticula. Clin Radiol 1991;44:125-127.

103 Silen W, Sheiman RG: Giant colonic diverticulum. N Engl J Med 1995;333:1645.

104 Painter NS, Burkitt DP: Diverticular disease of the colon: A deficiency disease of Western civilization. Br Med J 1971;2:450-454.

105 Gooszen AW, Gooszen HG, Veerman W, et al: Operative treatment of acute complications of diverticular disease: Primary or secondary anastomosis after sigmoid resection. Eur J Surg 2001;167:35-39.

\title{
Invited Commentary
}

\author{
Susan Galandiuk
}

Department of Surgery, School of Medicine, University of Louisville, Louisville, Ky., USA

The authors present a comprehensive review of a rare but clinically significant condition, that of giant colonic diverticula. They highlight that although this type of diverticulum is uncommon, such diverticula are associated with significant complications in nearly a third of the patients, perforation and abscess formation being the two most common. The authors highlight the possibility that a ball-valve-type mechanism may cause these diverticula to grow larger and larger, and, in fact, of those cases that they reviewed, the majority were type II diverticula, which had resulted from an occult colonic perforation resulting in a chronic fibrotic 'diverticular cavity'. Abdominal pain was the predominant symptom in patients presenting with symptomatic giant colonic diverticula, and this was in many cases associated with a palpable abdominal mass that could be associated with fever. Plain abdominal Xrays, computed tomography, and barium enema seem to be the most useful diagnostic tests. Although the operative mortality is quoted as being $5 \%$, with most of the data coming from case reports, it is hard to make conclusions about surgery. Due to the high rate of complications, such diverticula should be treated electively. Importantly, the authors report a $2 \%$ incidence of carcinoma developing inside these diverticula, which, given their location and poor endoscopic visibility, could be difficult to diagnose at an early stage. With today's minimal access surgery making elective colon resection a less morbid procedure for the patient in terms of recovery time and incisional pain, elective segmental colectomy of the involved segment is the preferable treatment. 